\title{
Prioritizing the Weightage of Sustainability Criteria and Sub-Criteria of Decentralized Micro-Hydropower Projects for Rural Electrification in Nepal
}

\author{
Rana Bahadur Thapa* Bishnu Raj Upreti Durga Devkota Govind Raj Pokharel \\ Department of Rural Sociology and Development Studies, Agriculture and Forestry University, Rampur, \\ Chitwan, Nepal
}

\begin{abstract}
In many cases, sustainability of renewable energy systems (RES) is being analyzed by identifying certain criteria and sub-criteria considering equal weightage among the respective groups. However in reality, relative weightage of criteria and sub-criteria vary due to many reasons. Thus, this paper tries to prioritize the weightage of criteria and sub-criteria of decentralized micro-hydropower projects for rural electrification by analyzing sustainability indicators related to four dimensions- technical, social, economic, and environmental. An Analytical Hierarchy Process -Online Software (AHP-OS) model is used to prioritize the weightage of respective criteria and subcriteria through expert opinion. Suitable goal, criteria and sub-criteria are developed after reviewing pertinent literature and consultation of the experts. The results reveal that technical criteria $(0.362)$ is the most crucial sustainability criteria followed by economic (0.290) and social (0.226). Environmental criteria (0.122) is found to be the least preferred criteria. The results reveal that 'energy availability' $(10.8 \%)$ is observed to be the most preferred and 'GSI inclusion' $(2.4 \%)$ is ranked to be the least preferred sub-criteria among the 19 sub-criteria. Nepal, being a developing country, shows a trend of people preferring the development of energy services first at a relatively low cost without considering the environment and gender/social inclusion. As a result, technical and economic criteria and sub-criteria are preferred more than that of environmental and social. The outcome of the research can help decision-makers and policy-makers in shaping energy policies, plans, and programs, and foster future pathways for providing sustainable rural electrification in the country.
\end{abstract}

Keywords: Indicators, Sustainability, Multi-criteria analysis, Prioritizing, Pairwise

DOI: $10.7176 /$ JETP/9-9-02

Publication date: December $31^{\text {st }} 2019$

\section{Introduction}

Access to modern energy enables an environment to improve the quality of life of rural households, increase livelihood opportunities, and improvise services of public institutions. It is key for reducing poverty and raising living standards (Zen et al. 2016). Providing modern energy services is possible by either expanding grid or developing decentralized energy systems based on available local resources. Due to scattered settlements and geological situations, decentralized electrification is taking place for providing modern electricity service to the rural people of Nepal. Electrification from micro-hydro projects (MHPs) is one of the major decentralized electrification solutions in Nepal (Thapa 2017). With subsidy from Alternative Energy Promotion Centre (AEPC), more than 1800 MHPs are already installed providing electricity to more than 320,000 households (AEPC 2018). Based on demand, projects are promoted but there is no provision to systematically assess whether the installed plants are able to provide service in a sustainable manner or not. In many cased sustainability of energy systems is analyzed considering equal weightage of sustainability criteria and sub-criteria, as in reality, subjectivity embedded in the choice of sub-criteria weights and rankings in the multiple-indicator approach (Bhattacharyya 2012).

The authors intend to assess the installed micro-hydropower projects with the help of mostly-used sustainability criteria around the globe based on the priority weightage identified from expert opinion. In the first phase of the research, the authors have tried to find out relative weightage of each criteria and sub-criteria considering the overall sustainability of installed projects. One of the solutions for prioritizing these criteria (dimensions) and sub-criteria (indicators) is the analysis of sustainability indicators of renewable energy systems with the help of multi-criteria decision making method (MCDM). Many studies have used multi-criteria sustainability analysis based on sustainability indicators for solving such problems related to decentralized/rural electrification, and some of these are summarized hereunder:

Ilskog (2008) proposes a method for sustainability assessment of rural electrification projects being implemented in developing countries based on 39 indicators and five dimensions (technical, economic, social/ethical, environmental, and institutional). The author suggests to have interdisciplinary approach to improve a basis for sustainability evaluation, as the projects promoted based on certain prioritized dimensions, such as environment, may fail as a result of weaknesses in the other dimensions.

Providing an integrated decision aid framework, Mamlook et al. (2001) deal with neuro-fuzzy method to 
solve the problems of selecting the most suitable electric power generation system alternatives for Jordan. They have ranked the five technologies (fossil fuel, hydro, wind, solar, and nuclear) based on mainly costappropriateness.

Wang et al. (2009) employ an extensive review of different stages of multi-criteria decision making for sustainable energy, i.e. selection, weighting, evaluation and final aggregation of criteria and propose four sustainability dimensions (technical, social, economic, and environmental). The authors conclude that criteria weights influence directly the decision making results of alternatives.

Demirtas (2013) assesses four sustainability dimensions (technical, social, economic, and environmental) for ranking five energy technologies (geothermal, solar, wind, hydropower, and biomass). They have used criteria weightage determined by pairwise comparison matrices of the AHP.

Şengül et al. (2015), in their studies, have investigated nine indicators and four sustainability dimensions (technical, economic, social, and environmental) by using MCDM technique-fuzzy TOPSIS method for ranking renewable energy supply systems in Turkey. Though they have identified 24 indicators, only nine are selected considering the availability of information from the literature and they excluded the experts' opinion.

With the help of secondary information, Evans et al (2009) have assessed four technologies (PV, wind, hydro, and geothermal) based on sustainability indicators and came up with ranking the technologies. They have assumed that each indicators has an equal importance for sustainable development.

In order to provide energy for water pumping in Nepal, Dhital et al. (2016) have performed ranking of five energy systems (diesel generator, wind power, hydropower, solar PV with battery, and without battery. They have come with different criteria weightage determined by pairwise comparison matrices with respect to the goal (ranking alternatives)

Recently, considering four sustainability criteria and 11 sub-criteria, Dhital et al. (2018) evaluate four selected alternatives (grid, micro-hydro, solar, and biomass). They applied AHP method and come up with grid technology (centralized electricity) to be the most suitable and biomass to be the least suitable alternative energy system in Nepal. The authors have come up with varied weightage criteria and sub-criteria that are determined from experts' opinion through pairwise comparisons matrices with respect to the goal (ranking alternatives).

Singh and Nachtnebel (2016) deploy AHP method to prioritize grid-connected hydropower development in Nepal based on selected six-goals, five alternatives, five criteria (technical, social, environmental, economic, and political) and 23 sub-criteria. These criteria have been weighted differently. Based on responses from experts' survey, the most prioritized weightage is given to economic criteria $(24.4 \%)$ followed by political $(21.0 \%)$, technical $(20.15 \%)$, social $(18.9 \%)$, and environmental $(15.5 \%)$ criteria. In their findings, they conclude that medium scale hydropower is most preferred among the five alternatives that were focused on large and grid connected projects.

Bhandari at al. (2018) have performed field based study on sustainability of a micro-hydropower project in Nepal considering four criteria (social, economic, environmental, and technical), 54 sub-criteria, and scoring system ( 1 to 5 , with 5 being the best).

Some studies have focused on different energy technologies for providing energy services in general and some are focused on country specific contexts. In other cases, the priority weightage is of each criteria is treated equally. In addition, there are very limited studies carried out specially focusing on single technology especially pointing out decentralized energy services and dealing with varied preference of each indicators. Therefore, this paper aims to contribute in fulfilling this gap to prioritize the weightage of sustainability criteria and sub-criteria of operational decentralized micro-hydropower projects in Nepal. We have proposed an Analytical Hierarchy Process-Online Software (AHP-OS) as an appropriate tool for decision making process in Nepalese context. Furthermore, AHP-OS method is a paperless approach that will further ensure to check the consistency ratio by the respective respondents during the survey. Consequently, the researcher may not need to further modify the acquired information like in paper based survey tools.

We have selected four criteria (dimensions) and 19 sub-criteria (indicators) after reviewing pertinent literature and consultation of experts. Then, we have placed the selected criteria and sub-criteria based on AHP principle. Consequently, suitable goal, criteria and sub-criteria were placed in hierarchy structure (Figure 1). To carry out paperless survey, a separate website (Thapa 2019) is developed to provide relevant information to potential respondents before participating in online survey that is linked to AHP-OS tool.

The results of the study shows that technical criteria is the most crucial criteria for sustainability of decentralized rural electrification with priority weight 0.362 followed by economic $(0.290)$ and social $(0.226)$ criteria. Environmental criteria $(0.122)$ is found to be the least preferred sustainability criteria. It is found that the AHP-OS model enables a basis for prioritizing the criteria and sub-criteria for analyzing sustainability assessment of energy system; providing an effective decision making tool for rural electrification and development field.

This paper has the following structure: Section-1 includes the introduction and a concise discussion of the state-of-the-art in sustainability of energy system, and status of decentralized micro-hydropower in Nepal. In Section-2, presents the models and methodology for sustainability assessment that includes establishment of 
decision-support framework, and step-to-step process of Analytical Hierarchy Process (AHP) method for decision making process. Section-3 and 4 highlight the results of empirical analysis and discussion based on local stakeholders'/experts' preference in prioritizing sustainability criteria and sub-criteria of existing microhydropower projects in Nepalese context. Finally, Section-5 concludes the study specifying the main outcomes of the study.

Sustainability of Energy System: Brundtland et al. (1987) defined - "Sustainable development is development that meets the needs of the present without compromising the ability to future generations to meet their needs". The United Nations has endorsed to implement global initiatives- Sustainable Development Goals (SDGs) i.e. decision made by the UN Conference on Sustainable Development held in Rio de Janeiro in June 2012 and the UN General Assemblies held in September 2014 and 2015 (NPC 2017). Most of the countries including Nepal, have already committed to implement the SDGs. The SDG-7 aims to "ensure access to affordable, reliable, sustainable and modern energy for all" as one of 17 goals for 2030 (ESMAP 2017). Nepal, being a member state of the United Nations, is committed to these global initiatives. Besides meeting the global and national commitments, the sustainable development of energy system is being increasingly more important for policymakers and decision-makers worldwide (Santoyo-Castelazo \& Azapagic 2014). Meeting the sustainability of energy systems, it requires consideration and integration of four main sustainability aspects of energy system: technical, social, economic, and environmental. This aspect is progressively being adapted by policy-makers and decision-makers and is reveled in many studies that have considered the sustainability of energy systems mainly in electrification rather than heating (Santoyo-Castelazo \& Azapagic 2014; Ciroth et al. 2011).

Micro-hydropower project as a Decentralized Electrification: Micro-Hydropower Project (MHP) is a matured technology for decentralized electrification solution in Nepal. Mainly hills and mountain regions of the country is preferably suitable for MHP due to abundantly available water resources, potential head and unavailability of grid-electricity. As per experts' survey carried out by Thapa et al. (2019) micro-hydropower is one of the most preferred decentralized rural electrification solution in Nepal. It is a mini-grid solution working as an isolated manner with relatively low generation $(1-100 \mathrm{~kW})$, low-voltage distribution grid $(400 \mathrm{~V}$ or $11 \mathrm{kV})$ that provides electricity to a community, village or a small town (UNDP 2014). It is one of the mature technologies in Nepal. Though electrification from hydropower was initiated during 1960s, development of decentralized hydropower was mainstreamed only after establishment of AEPC in 1996 (WB 2015). Similarly, runoff river types of projects are designed considering 11-month flow exceedance to ensure designed power be available at least 92 percentage of time in a year (AEPC 2008; AEPC 2014).

As per AEPC database more than 1800 MHPs are operating and about 100 MHPs are in under construction stage (AEPC 2018). And these MHPs are wide spread in the country especially in hilly areas covering 55 districts out of 77 districts (AEPC 2018). Districts in plain areas are not suitable for MHP due to lack of available head. Moreover, most of these districts are covered by the national grid. MHPs are providing energy for lighting, running small and medium size enterprises, and ensuring electricity to social services especially in the rural parts of the country.

\section{Models and Methodology}

\subsection{Establishing Decision-Support Framework}

The decision-support framework for determining local experts' preference on weightage of selected sustainability criteria (dimension) and sub-criteria (indicators) of decentralized electrification system is outlined in Figure 1. The selected decision-support framework involves the following procedures:

1. Selection of suitable tool- Analytical Hierarchy Process-Online Software (AHP-OS) as a multi-criteria decision making (MCDM) tool;

2. Selection of indicators for assessing sustainability of energy system;

3. Categorization of indicators in four-dimensions: technical, social, economic \& environmental;

4. Integration of sustainability dimensions and indicators via a multi-criteria decision analysis (AHP method) to determine the relative and global weightage of sustainability dimensions and indicators that determine the most suitable option for the future path.

\subsection{Analytical Hierarchy Process (AHP)}

The analytical hierarchy process (AHP) is a mathematical method for analyzing complex decision problems under multiple criteria (Thapa et.al. 2019; T. L. Saaty 1994). In this method, three basic principles- decomposition, comparative judgment and synthesis of priorities are taken into account in problem solving. In the decomposition principle, structuring of the hierarchy is performed in which the problem to be solved is kept on the top followed by criteria in the second level, sub-criteria is placed in the third level, and alternative solutions are kept at the bases. At the intermediate levels, different criteria which are the basis of decision making are kept (Thapa et al. 2019; T. L. Saaty \& Vargas 2012).

The principle of comparative judgments stand for setting up a matrix to carry out pairwise comparisons of 
the relative importance of the elements in the second level with respect to the overall objective of the first level. The scale for entering judgments is given in Table 1 Additional comparison matrices are used to compare the elements of the third level with respect to the appropriate parents in the second level and so on down the hierarchy (Thapa et al. 2019; T. L. Saaty 1986).

The synthesis of priority principle stands for synthesizing the priorities from the second level down by multiplying local priorities by the priority of the corresponding criterion in the level above and adding them for each element in a level according to the criteria it affects. This gives the composite or global priority of that element (Thapa et al. 2019; T. L. Saaty 1986).

One of the characteristics of the AHP is that it provides a model for decision-making, ranking and prioritizing the problem that is flexible in a user-friendly manner. Comparison values can be acquired from surveys or measurement from the respondents using fundamental scales. For prioritizing sustainability criteria and subcriteria (indicators) of decentralized micro-hydropower projects in Nepal, AHP applied in the following five steps (Brent \& Rogers 2010; Thapa et.al. 2019; T. L. Saaty 1994).

Step 1: Problem hierarchy:

The research goal (prioritizing sustainability criteria and sub-criteria of installed micro-hydropower projects in Nepal) is located at the top-level. At the second level, themes/criteria are located which are further divided into sub-criteria according to the level of detail required. The criteria/sub-criteria is defined as a set of attributes that allow the decision makers to set preferences. All the solution-alternatives are placed at the bottom of the hierarchy in order to a make final decision (Thapa et al. 2019; T. L. Saaty 1994).

The four sustainability dimensions/criteria that are considered to analyze sustainability indicators of installed MHPs for rural electrification in Nepal is: technical, social, economic, and environmental. And various 19 subcriterion/indicators are considered within each of the four dimensions to measure/compare the sustainability of installed MHPs. Based on the AHP model, the hierarchical structures is shown in Figure 1.

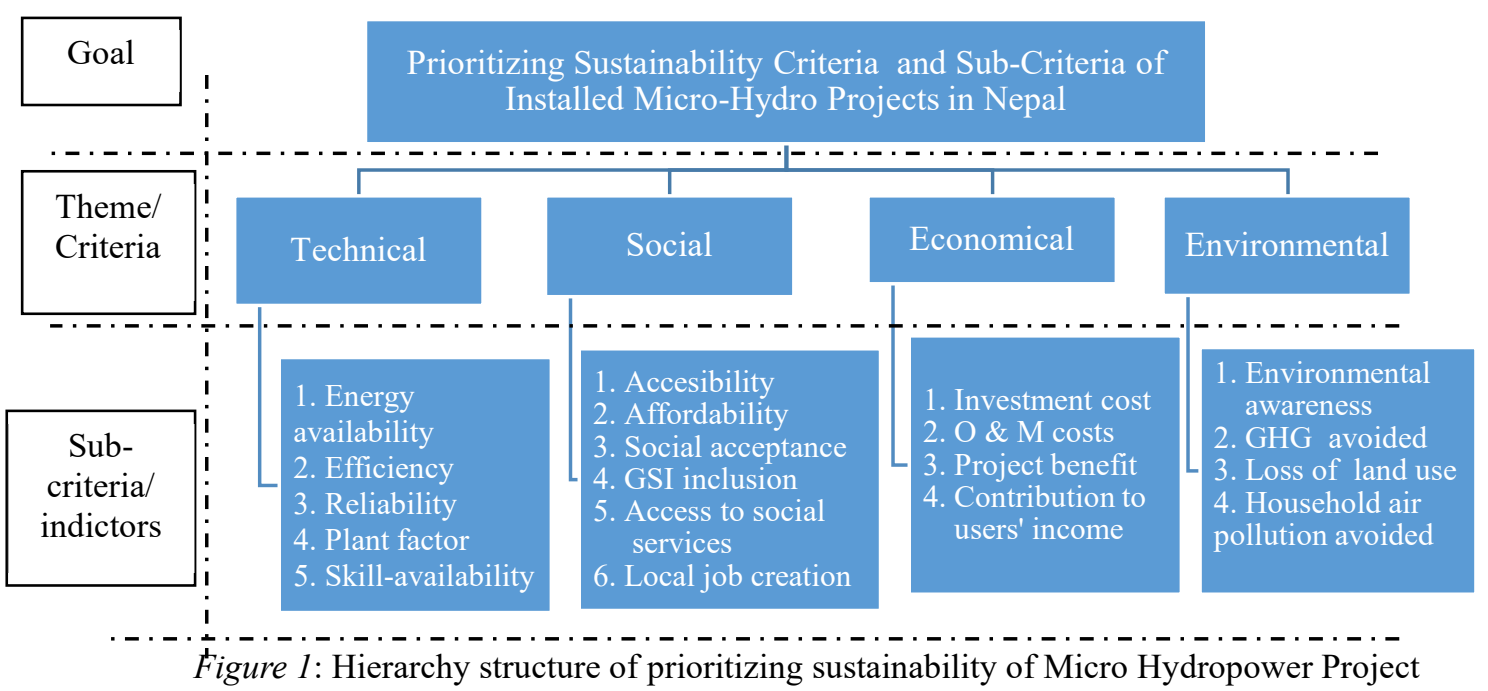

Step 2: Set of priorities for criteria and sub-criteria:

According to the preference of the decision makers, a numerical value shall be assigned to each criterion and subcriterion. As per Saaty, the nine-scale is proposed for assigning numerical value as per Table 1 In case of setting priorities for sub-criteria, a paired comparisons is formulated for establishing importance of the sub-criteria with respect to a higher level (T. L. Saaty 1986 ; T. L. Saaty \& Vargas 2012).

In the case of setting priorities for criteria, a paired comparisons is formulated for establishing preferences of the criteria with respect to higher levels i.e. goal of hierarchy structure (T. L. Saaty 1986). 
Table 1: Analytic Hierarchy Measurement Scale

\begin{tabular}{|c|l|l|}
\hline $\begin{array}{l}\text { Reciprocal Measure of } \\
\text { Intensity of Importance }\end{array}$ & Definition & Explanation \\
\hline 1 & Equal importance & $\begin{array}{l}\text { Two activities contribute equally to the } \\
\text { objective activity over another }\end{array}$ \\
\hline 3 & $\begin{array}{l}\text { Moderate importance of one } \\
\text { over another }\end{array}$ & $\begin{array}{l}\text { Experience and judgment slightly favor one } \\
\text { activity over another }\end{array}$ \\
\hline 5 & Strong importance & $\begin{array}{l}\text { Experience and judgment strongly favor one } \\
\text { activity over another }\end{array}$ \\
\hline 7 & Very strong importance & $\begin{array}{l}\text { Activity is strongly favored and its dominance is } \\
\text { demonstrated in practice. }\end{array}$ \\
\hline 9 & Extreme importance & $\begin{array}{l}\text { The evidence favoring one activity over another } \\
\text { is of the highest possible order of affirmation }\end{array}$ \\
\hline $2,4,6,8$ & $\begin{array}{l}\text { Intermediate values between } \\
\text { two adjacent judgments }\end{array}$ & When compromise is needed \\
\hline Reciprocal of above & $\begin{array}{l}\text { If activity } \mathrm{i} \text { has one of the above non-zero numbers assigned to it when compared } \\
\text { with activity } \mathrm{j}, \text { then } \mathrm{j} \text { has the reciprocal value when compared with } \mathrm{i} .\end{array}$ \\
\hline
\end{tabular}

Step 3: Formulation of pair-wise questionnaires:

$$
\text { Source: (T. L. Saaty 1986) }
$$

Based on nine-point scale, a pairwise comparison is formulated for criteria and sub-criteria with respect to the higher level in order to acquire judgment from the experts (R. W. Saaty 1987).

Step 4: Define global weight for criteria and sub-criteria:

Global weight for the criteria and sub-criteria (indicators) is obtained from the multiplication of the local or relative weight $\left(\mathrm{w}_{\mathrm{i}}\right)$ by the global weight of the immediately superior criterion. The sum of the global weights of the alternatives in relation to each criterion is the mechanism to obtain the prioritizing weightage of sustainability of all possible criteria and sub-criteria. The weights of each alternative within them are computed using:

$$
A_{w}=\lambda_{\max } \times w \ldots \ldots \text { (1) }
$$

Where, $\mathrm{A}$ is the comparison matrix of size $\mathrm{n} \mathrm{x} \mathrm{n}$ for $\mathrm{n}$ criteria. It is also called the priority matrix and $\mathrm{w}$ is the Eigenvector of size $\mathrm{n} \times 1$, also called the priority vector, which is the weight. $\kappa_{\max }$ is the maximum Eigenvalue (T. L. Saaty 1994). Eigenvector and priority vector could be obtained by solving for the principle Eigenvector. Though there are many means to solve the priority vector, an easy way to get an approximation of the priorities is to normalize the geometric means of the rows (R. W. Saaty 1987).

Step 5: Verify the consistency of the judgments:

Finally, the consistency index is used to measure the degree of consistency of the estimation. The consistency index $(\mathrm{CI})$ is calculated by:

$$
C I=\frac{\lambda_{\max }-n}{n-1}
$$

In order to verify the CI values, a comparison is made with the random consistency index (RI). This parameter is defined as an average of the CIs of the large set of matrices with random inputs (T. L. Saaty \& Vargas 2012). In addition, Saaty defines the consistency ratio $(\mathrm{CR})=\mathrm{CI} / \mathrm{RI}$. If $\mathrm{CR} \leq 0.1$, the results are consistent. If $\mathrm{CR}>0.1$, the data are inconsistent and the decision makers' judgments need to be reviewed.

Table 2: Random Consistency Index (RI)

\begin{tabular}{|c|c|c|c|c|c|c|c|c|c|c|}
\hline $\boldsymbol{N}$ & $\mathbf{1}$ & $\mathbf{2}$ & $\mathbf{3}$ & $\mathbf{4}$ & $\mathbf{5}$ & $\mathbf{6}$ & $\mathbf{7}$ & $\mathbf{8}$ & $\mathbf{9}$ & $\mathbf{1 0}$ \\
\hline $\mathrm{RI}$ & 0 & 0 & 0.52 & 0.89 & 1.11 & 1.25 & 1.35 & 1.40 & 1.45 & 1.49 \\
\hline
\end{tabular}

Source: (T. L. Saaty \& Vargas 2012)

\subsection{Sustainability dimensions and indicators (criteria and sub-criteria)}

Zen et al. (2016) points out that measuring sustainability is a major challenge and a key issue for discussion on sustainable development. Developing a reliable tool to measure sustainability is a pre-requisite for policy-makers and decision-makers to distinguish whether they are fostering sustainable development or should be re-adjusted (Zen et al. 2016). Therefore establishing reliable and measurable sustainability criteria and sub-criteria is important that needs to be continuously monitored.

Establishing sustainability criteria and sub-criteria:

Traditionally technical and economic criteria were considered in decision making that could not be coherent with the development of electric system based on the developmental conditions and protection of local environment. Due to this, social and environmental considerations were poorly explored though these factors would contribute to robustness in sustainable decentralized energy (Rojas-Zerpa \& Yusta 2015). Therefore, technical, economic, 
social and environmental criteria are considered to implement in the study. Different literature related to problems of energy planning, implementation, evaluation etc. using multi-criteria decision making (MCDM) tools are reviewed in order to establish the criteria and sub-criteria. Then, consulting with experts from academic, private sector, public sectors and non-governmental organizations, the final sub-criteria are established. In such a way, a list of 19 sub-criteria are prepared and then are grouped into four criterion: technical, social, economic and environmental. Then after, selected sub-criteria are clustered in four criteria. The final criteria and sub-criteria with description are shown in the following Table 3.

Table 3: Selected sub-criteria and their description for analyzing sustainability of MHPs

\begin{tabular}{|c|c|c|c|}
\hline 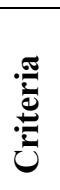 & $\begin{array}{l}\text { Sub-criteria/ } \\
\text { Indicators }\end{array}$ & Description of Indicators (Units) & References \\
\hline \multirow{6}{*}{ :ׁ } & \multicolumn{3}{|c|}{$\begin{array}{l}\text { Technical sustainability of electrification focuses on the system's capacity of providing the efficient and } \\
\text { reliable energy services throughout its economic lifespan. }\end{array}$} \\
\hline & $\begin{array}{l}\text { Energy } \\
\text { availability }\end{array}$ & $\begin{array}{l}\text { It is a serviceability performance of energy } \\
\text { supply to the consumers i.e. amount of } \\
\text { electricity provided/ generated from the } \\
\text { technical system. }\end{array}$ & $\begin{array}{l}\text { (Ilskog 2008; Thapa et al. 2019; Onat } \\
\text { \& Bayar 2010; Demirtas 2013; } \\
\text { Mainali \& Silveira 2015; Bhandari et } \\
\text { al. 2018; Singh \& Nachtnebel 2016) }\end{array}$ \\
\hline & Efficiency & $\begin{array}{l}\text { Ability of technical system to convert the } \\
\text { primary energy source to electricity. }\end{array}$ & $\begin{array}{l}\text { (Ilskog 2008; Thapa et al. 2019; } \\
\text { Algarín, Llanos, \& Castro 2017; } \\
\text { Mainali \& Silveira 2015; Liu et al. } \\
\text { 2013; Kaya \& Kahraman 2010; Abreu } \\
\text { et al. 2018; AEPC 2016; UNDP 2007) }\end{array}$ \\
\hline & Reliability & $\begin{array}{l}\text { Ability of the system to function/perform } \\
\text { according to design conditions for a specific } \\
\text { period of time and to support failures. }\end{array}$ & $\begin{array}{l}\text { (Thapa et al. 2019; Algarín et al. 2017; } \\
\text { Demirtas 2013; Mainali \& Silveira } \\
\text { 2015; Bhandari et al. 2018; Kaya \& } \\
\text { Kahraman 2010; Wang et al. 2009) }\end{array}$ \\
\hline & Plant factor & $\begin{array}{l}\text { The ratio of total energy ( } \mathrm{kWh}) \text { used divided by } \\
\text { the total energy available in certain period of } \\
\text { time. }\end{array}$ & $\begin{array}{l}\text { (Thapa et al. 2019; Bhandari et al. } \\
\text { 2018; AEPC 2016) }\end{array}$ \\
\hline & $\begin{array}{l}\text { Skill- } \\
\text { availability }\end{array}$ & $\begin{array}{l}\text { Level of skill available at the local level for } \\
\text { regular operation \& management of the system. } \\
\text { It is the stage of availability of spare } \\
\text { parts/trained operators and a level of know- } \\
\text { how for replacement \& repair. }\end{array}$ & $\begin{array}{l}\text { (Ilskog 2008; Thapa et al. 2019; } \\
\text { Algarín et al. 2017; Ilskog \& } \\
\text { Kjellström 2008; Afgan \& Carvalho } \\
\text { 2008) }\end{array}$ \\
\hline \multirow[t]{5}{*}{ 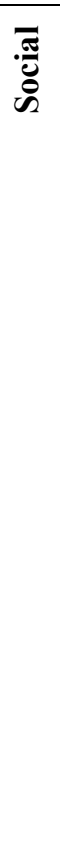 } & \multicolumn{3}{|c|}{$\begin{array}{l}\text { Social sustainability focuses on the equitable distribution of benefits offered by and social acceptance of } \\
\text { electrification that can be captured by enabling the technological intervention in the fundamental social } \\
\text { services e.g. health, education, agriculture, communication \& information and contributing to poverty } \\
\text { reduction by fostering income generation opportunities to the locals so that everyone irrespective of any } \\
\text { economic, social or gender disparity can make the use of service. }\end{array}$} \\
\hline & Accessibility & $\begin{array}{l}\text { Accessibility is the proportion of households in } \\
\text { the catchment area that has access to electricity. }\end{array}$ & $\begin{array}{l}\text { (Thapa et al. 2019; Liu et al. 2013; } \\
\text { AEPC 2016; Feron, Heinrichs, \& } \\
\text { Cordero 2016a ; IAEA 2005) }\end{array}$ \\
\hline & Affordability & $\begin{array}{l}\text { The ratio of household income spent on fuels } \\
\text { and electricity to the total household income. It } \\
\text { also refers to users' perception of electricity } \\
\text { prices. }\end{array}$ & $\begin{array}{l}\text { (Brent \& Rogers 2010; Thapa et al. } \\
\text { 2019; IAEA 2005; Hong \& Abe 2012) }\end{array}$ \\
\hline & $\begin{array}{l}\text { Social } \\
\text { acceptability }\end{array}$ & $\begin{array}{l}\text { Willingness of the community to accept the } \\
\text { implementation of the system in their locality. }\end{array}$ & $\begin{array}{l}\text { (Thapa et al. 2019; Algarín et al. 2017; } \\
\text { Demirtas 2013; Bhandari et al. 2018; } \\
\text { Kaya \& Kahraman 2010; Feron et al. } \\
\text { 2016a; Wang et al. 2009; Hong \& Abe } \\
\text { 2012; Feron 2016; Amer \& Daim } \\
\text { 2011) }\end{array}$ \\
\hline & $\begin{array}{l}\text { Gender and } \\
\text { social (GSI) } \\
\text { inclusion }\end{array}$ & $\begin{array}{l}\text { Gender and social inclusion in management } \\
\text { committee ( } \% \text { of participation }) \text {. }\end{array}$ & $\begin{array}{l}\text { (Thapa et al. 2019; Singh \& } \\
\text { Nachtnebel 2016; AEPC 2016) }\end{array}$ \\
\hline
\end{tabular}




\begin{tabular}{|c|c|c|c|}
\hline$\stackrel{\pi}{\underline{3}}$ & $\begin{array}{l}\text { Sub-criteria/ } \\
\text { Indicators }\end{array}$ & Description of Indicators (Units) & References \\
\hline & $\begin{array}{l}\text { Access to } \\
\text { social services } \\
\text { (Social } \\
\text { benefits) }\end{array}$ & $\begin{array}{l}\text { The capacity of the system to supply energy in } \\
\text { schools and health posts or energy access to } \\
\text { social services [e.g. health, education, public } \\
\text { buildings, information- communication- } \\
\text { technology, agriculture facility] }\end{array}$ & $\begin{array}{l}\text { (Ilskog 2008; Thapa et al. 2019; } \\
\text { Algarín et al. 2017; Demirtas 2013; } \\
\text { Bhandari et al. 2018; Kaya \& } \\
\text { Kahraman 2010; Amer \& Daim 2011; } \\
\text { Doukas, Andreas, \& Psarras 2007) }\end{array}$ \\
\hline & $\begin{array}{l}\text { Employment } \\
\text { generation }\end{array}$ & $\begin{array}{l}\text { Nos. of direct and indirect employment } \\
\text { generated at local level. }\end{array}$ & $\begin{array}{l}\text { (Ilskog 2008; Brent \& Rogers 2010; } \\
\text { Thapa et al. 2019; Algarín et al. 2017; } \\
\text { Mainali \& Silveira 2015; Bhandari et } \\
\text { al. 2018; Liu et al. 2013; Kaya \& } \\
\text { Kahraman 2010; Amer \& Daim 2011) }\end{array}$ \\
\hline \multirow{5}{*}{ 莺 } & \multicolumn{3}{|c|}{$\begin{array}{l}\text { A project is economically sustainable if its revenue suffices for smooth operation to provide electricity } \\
\text { services to its clients and it can manage repair and maintenance till its lifespan. }\end{array}$} \\
\hline & $\begin{array}{l}\text { Per unit } \\
\text { investment } \\
\text { cost }\end{array}$ & $\begin{array}{l}\text { It refers to the per unit initial investment cost } \\
\text { of energy system (US } \$ \mathrm{~kW}) \text {. Investment cost } \\
\text { consists of total expenses occurred while } \\
\text { establishing the system e.g. equipment, } \\
\text { construction, labor, infrastructure, installation } \\
\text { and commissioning costs. }\end{array}$ & $\begin{array}{l}\text { (Ilskog 2008; Thapa et al. 2019; } \\
\text { Demirtas 2013; Mainali \& Silveira } \\
\text { 2015; Bhandari et al. 2018; Kaya \& } \\
\text { Kahraman 2010; Abreu Kang et al. } \\
\text { 2018; Feron et al. 2016a; Wang et al. } \\
\text { 2009; Ahmad \& Tahar 2014) }\end{array}$ \\
\hline & $\begin{array}{l}\text { Operation \& } \\
\text { Maintenance } \\
(\text { O\&M) cost }\end{array}$ & $\begin{array}{l}\text { It refers to the cost for regular operation and } \\
\text { maintenance of the energy system like: } \\
\text { salaries, stationeries, repair etc. }\end{array}$ & $\begin{array}{l}\text { (Ilskog 2008; Thapa et al. 2019; } \\
\text { Demirtas 2013; Mainali \& Silveira } \\
\text { 2015; Bhandari et al. 2018; Kaya \& } \\
\text { Kahraman 2010; Abreu Kang et al. } \\
\text { 2018; AEPC 2016; Feron et al. 2016a; } \\
\text { Wang et al. 2009; Ahmad \& Tahar } \\
\text { 2014) }\end{array}$ \\
\hline & $\begin{array}{l}\text { Project Benefit } \\
\text { (Profitability) }\end{array}$ & $\begin{array}{l}\text { It is the level of income earned by the system } \\
\text { in order to operate until its life span. }\end{array}$ & $\begin{array}{l}\text { (Brent \& Rogers 2010; Thapa et al. } \\
\text { 2019; Demirtas 2013; Bhandari et al. } \\
\text { 2018; Liu et al. 2013; Wang et al. } \\
\text { 2009; IAEA 2005; Doukas et al. 2007; } \\
\text { Kumar et al. 2017) }\end{array}$ \\
\hline & $\begin{array}{l}\text { Contribution } \\
\text { to users' } \\
\text { income }\end{array}$ & $\begin{array}{l}\text { Change in level of income before and after } \\
\text { energy services ( } \% \text { change). }\end{array}$ & $\begin{array}{l}\text { (Ilskog 2008; Brent \& Rogers 2010; } \\
\text { Thapa et al. 2019; Ilskog \& Kjellström } \\
\text { 2008; Bhandari et al. 2018; AEPC } \\
\text { 2016; Hong \& Abe 2012) }\end{array}$ \\
\hline \multirow{4}{*}{ 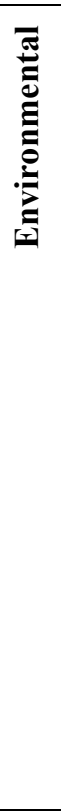 } & \multicolumn{3}{|c|}{$\begin{array}{l}\text { Environmental sustainability aims to reduce the local and global impact in the environment by } \\
\text { contributing to minimizing the negative impacts of energy solution on the environment. It focuses on the } \\
\text { adaptation of national regulation, civil society's awareness on environmental issues. }\end{array}$} \\
\hline & $\begin{array}{l}\text { Environmental } \\
\text { Awareness }\end{array}$ & $\begin{array}{l}\text { Awareness is the consciousness of society } \\
\text { about the environment. It is the level of } \\
\text { awareness during the planning, construction } \\
\text { and operation phase. }\end{array}$ & $\begin{array}{l}\text { (Thapa et al. 2019, Feron, Heinrichs, } \\
\& \text { Cordero 2016a, Feron et al., 2016b) }\end{array}$ \\
\hline & GHG avoided & $\begin{array}{l}\text { Annual GHG emission avoided from energy } \\
\text { production and use. }\left(\mathrm{kg} \mathrm{CO}_{2} \mathrm{eq} . / \mathrm{kWh}\right. \\
\text { avoided). }\end{array}$ & $\begin{array}{l}\text { (Ilskog 2008; Thapa et al. 2019; PwC } \\
\text { 2016; Onat \& Bayar 2010; Demirtas } \\
\text { 2013; Bhandari et al. 2018; Singh \& } \\
\text { Nachtnebel 2016; Kemmler \& Spreng } \\
\text { 2007; UNDP 2007; IAEA 2005; Amer } \\
\text { \& Daim 2011; Ahmad \& Tahar, 2014) } \\
\end{array}$ \\
\hline & $\begin{array}{l}\text { Loss of land } \\
\text { use }\end{array}$ & $\begin{array}{l}\text { It is the loss of land use in energy generation } \\
\text { and consumption. }\end{array}$ & $\begin{array}{l}\text { (Thapa et al. 2019; Algarín et al. 2017; } \\
\text { Onat \& Bayar 2010; Mainali \& } \\
\text { Silveira 2015; Bhandari et al. 2018; } \\
\text { Kaya \& Kahraman 2010; UNDP } \\
\text { 2007; Wang et al. 2009; IAEA 2005; } \\
\text { Amer \& Daim 2011; Ahmad \& Tahar } \\
\text { 2014) }\end{array}$ \\
\hline
\end{tabular}




\begin{tabular}{|l|l|l|l|}
\hline Sub-criteria/ & Description of Indicators (Units) & References \\
\hline \multirow{2}{\text{Indicators}}{} & $\begin{array}{l}\text { Household air } \\
\text { pollution } \\
\text { (HAP) } \\
\text { avoided }\end{array}$ & $\begin{array}{l}\text { Household air pollution from kerosene and } \\
\text { diesel use avoided by the plant resulting in a } \\
\text { positive impact on health (eye irritation, } \\
\text { asthma, etc.) before and after the energy } \\
\text { system. (\% changes in cases) }\end{array}$ & $\begin{array}{l}\text { Nachtnebel 2016; Kaya \& Kahraman } \\
\text { Silveira 2014) }\end{array}$ \\
\hline
\end{tabular}

\subsection{Survey and Data}

Different researchers have used a various numbers of experts to acquire their judgments. Some researchers debate that the respondents should be well aware of the criteria and sub-criteria with pre-knowledge based on academic and/or professional experience. A systematic guide for AHP application and survey procedures are illustrated in various studies (Saaty T.L. 2008; Singh \& Nachtnebel 2016; Qureshi \& Harrison 2003). Heterogeneity is essential in the decision-making process to ensure different judgments are involved and various perceptions are considered (Al Garni et al. 2016). In this research, heterogeneity is ensured by selecting an expert panel from all sectors that are clustered in five sectors for the AHP model.

In this research, a purposive random selection method has been applied to select potential respondents. Five clusters are chosen based on intensive involvement in the development of micro-hydropower projects in Nepal. From each cluster, about 30 potential experts are selected assuming to get response from at least half of them. Online questionnaires have been distributed to 150 experts. Distribution of selected experts in five different sectors/clusters are as per following:

- Government sector: Central, provincial, local level governmental organizations.

- Development partner/INGO: International development agencies working in energy sector.

- Private sector: consultants, firms, installers, manufacturers, financial institutions

- Academic sector: University professors, researchers etc. involving in energy sector.

- Developers/NGOs: Community organizations, owners, NGOs working in energy sector.

Analytical Hierarchy Software-Online Software (AHP-OS) Tool: Business Performance Management Singapore (BPMSG) was has been used to carry out survey, compilation and analysis of the data (Goepel 2018). All the respondents has given detailed information about the criteria/dimensions, and sub-criteria (indicators) for the development of decentralized electrification from micro-hydropower projects in Nepal by developing a separate website (Thapa 2019). The website includes: informed consent form, detail information-pairwise comparison, step-to-step procedures for online survey, and link to AHP-OS software. They have been asked to compare the importance of criteria and sub-criteria for the installed MHPs in Nepal. A survey is conducted through online. Altogether 101 data sets were collected from the experts. Out of those, 10 data sets are invalid because of incompleteness and/or inconsistencies. Thus, complete responses received are found to be 91 which is $90.1 \%$ of accuracy.

\section{Results and empirical analysis}

Four-phases of the analysis have been carried out to find (i) consistency ratio, (ii) relative weights of criteria and sub-criteria, (iii) priorities of the criteria based on stakeholders' group, and (iv) priorities of sub-criteria based on stakeholders' group. In the first phase, the Consistency Ratio (CR) is considered, which should generally be less than 0.2 (Soma 2003). In this study, CR varies from 0 and 0.1 . The consistency of matrices in a pairwise comparison needs to be ensured. If the matrix is inconsistent, the respondents have been asked to make until it is achieved within the set value (i.e. 10\%), otherwise it is rejected.

\subsection{Experts' preference on criteria and sub-criteria based on relative weights}

Rojas et al. (2015), in their study have pointed out that 'the inclusion of experts in the decision-making process provides a realistic nature to decision-making, which is an added benefit in the search for electrical-supply solutions consistent with local sustainable development'. Considering the situation and with an aim to make it transparent and realistic, local experts' judgements were analyzed and presented in this section. In the second phase of the analysis, relative weightages of main-criteria and sub-criteria have been analyzed with the help of pairwise comparison received from different experts. The final result of relative weightages of both main-criteria and sub-criteria is presented in the following Table 4 
Table 4: Final relative weightage in relation to criteria and sub-criteria in AHP structure

\begin{tabular}{|c|c|c|c|c|}
\hline Goal & Criteria & Weights & Sub-criteria (Indicator) & Weightage \\
\hline \multirow{23}{*}{$\begin{array}{l}\text { Prioritizing } \\
\text { sustainability } \\
\text { criteria and sub- } \\
\text { criteria of installed } \\
\text { Micro-hydro } \\
\text { projects in Nepal }\end{array}$} & \multirow{6}{*}{ Technical } & \multirow{6}{*}{0.362} & Energy availability & 0.298 \\
\hline & & & Efficiency & 0.196 \\
\hline & & & Reliability & 0.253 \\
\hline & & & Plant factor & 0.150 \\
\hline & & & Skill-availability & 0.101 \\
\hline & & & Sub-total & 1.000 \\
\hline & \multirow{7}{*}{ Social } & \multirow{7}{*}{0.226} & Accessibility & 0.208 \\
\hline & & & Affordability & 0.267 \\
\hline & & & Social acceptance & 0.179 \\
\hline & & & Gender and social inclusion & 0.108 \\
\hline & & & Access to social services & 0.114 \\
\hline & & & Local job creation & 0.124 \\
\hline & & & Sub-total & 1.000 \\
\hline & \multirow{5}{*}{ Economic } & \multirow{5}{*}{0.290} & Unit investment cost & 0.310 \\
\hline & & & Operation and maintenance cost & 0.264 \\
\hline & & & Project benefit & 0.260 \\
\hline & & & Contribution to users' income & 0.167 \\
\hline & & & Sub-total & 1.000 \\
\hline & \multirow{5}{*}{ Environment } & \multirow{5}{*}{0.122} & Environmental awareness & 0.351 \\
\hline & & & Greenhouse gas avoided & 0.241 \\
\hline & & & Loss of land use & 0.202 \\
\hline & & & HHs air pollution avoided & 0.205 \\
\hline & & & Sub-total & 1.000 \\
\hline
\end{tabular}

Source: Authors' estimation (2019)

Comparing the relative weightages (refer Table 4) 'technical criteria', with priority weight 0.362 , is appeared to be the most crucial criteria in the determination of sustainability of decentralized electrification system. 'Economic criteria' (0.290) is found to be the second crucial criteria followed by 'social criteria' (0.226). 'Environmental criteria' (122) is appeared with the least significance in the Nepalese context. Similar results were observed from the past studies, for instance a study carried out by Dhital et al. (2018); Lee \& Chang, (2018), 'technical and economic criteria' are mostly prioritized whereas environment and social are found to be least preferred criteria for sustainability of renewable energy systems in Nepal and Taiwan respectively. However, in case of Turkey and Algeria 'environmental criteria' is found to be the most preferred from sustainability perspectives (Demirtas 2013; Haddad et al. 2017; Çolak \& Kaya 2017; Stojanovic 2013).

Similarly, looking into the relative weightage of sub-criteria under "technical criteria", 'energy availability" (0.289) is found to be the most crucial sub-criteria (indicator) followed by 'reliability' $(0.253)$ whereas 'skillavailability' $(0.101)$ is ranked to be the least prioritized indicator. In case of social criteria, 'affordability' $(0.267)$ followed by 'accessibility' $(0.208)$ become the most prioritized indicator and 'GSI inclusion' $(0.108)$ is appeared to be the least preferred indicator from the experts.

Similarly, in case of economic criteria, 'unit investment cost' $(0.310)$ is found to be the most crucial indicator followed by 'O\&M cost' and 'project benefit' and 'contribution to users' ( 0.167$)$ income' is ranked to be the least prioritized indicator. Similar result is seen with 'investment' and 'O\&M cost' being the most crucial in the study carried out by (Demirtas 2013).

Likewise in environmental criteria, 'environmental awareness' $(0.351)$ is ranked as the most prioritized indicator followed by potential of 'greenhouse gas avoided' whereas 'loss of land use' (0.202) appeared to be the least prioritized indicator from the experts.

\subsection{Aggregation of sustainability dimensions based on experts' preferences}

In order to see any variation in preference on four-dimensions based on five stakeholders' group were computed, which is illustrated in the following Figure 2. 


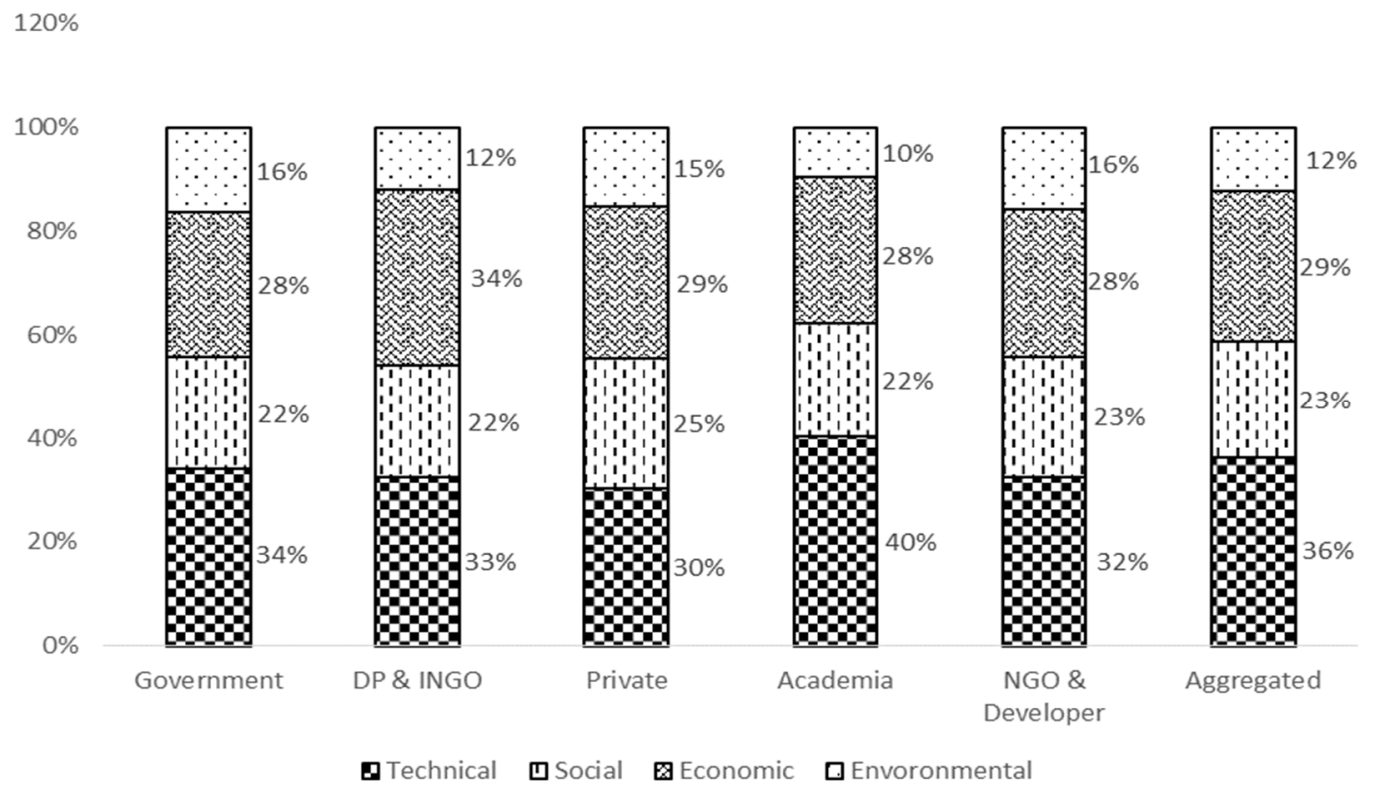

Figure 2: Distribution of weights for criteria among five-expert' groups

As per cumulative result (Figure 2), the local experts think that technical $(36 \%)$ is mostly preferred criteria followed by economic (29\%) and social (23\%). Whereas, environment (12\%) is least preferred criteria from local stakeholders' view. But, looking into individual preference from different stakeholders, it shows both convergence and divergence of preference among the groups. For instant, experts from development partners \& INGO group consider that economic (34\%) dimension is the crucial criteria for sustainability of energy systems in contrast to rest of the groups and private sector thinks that economic $(30 \%)$ and technical $(31 \%)$ have similar role in contribution to sustainability of energy system. Referring the past studies, for instance studies carried out by RojasZerpa \& Yusta (2015), the result is found to be more divergent. The academician preferred social criteria to be most preferred whereas, private sector preferred economic to be the most crucial criteria. Similarly, government (regulators) preferred environmental and NGO/developer (communities) preferred technical criteria to be the most crucial for sustainability of electric systems (Rojas-Zerpa \& Yusta 2015). As per them, the preference on the selected criteria may vary based on the background of the experts and they have suggested to incorporate relatively higher numbers of stakeholders' involvement in decision-making process that ensures participation, reality, transparency and legitimacy. However, in this case, there is not significance difference in mean value of weightage among the stakeholders group as per ANOVA test (ranges from $\mathrm{F}_{4,86}=0.257, \mathrm{p}>0.05$ to $\mathrm{F}_{4,86}=1.174, \mathrm{p}>0.05$ ). Therefore, it can be concluded that, the group results is converged to overall result, which implies that technical criteria is the most crucial for sustainability of energy system in Nepal followed by economic, social and environmental criteria.

\subsection{Experts' preferences on sub-criteria in consolidated form}

Similarly, consolidated (normalized) global priorities of 19-indicators (sub-criteria) is calculated and presented in the following Figure 3 


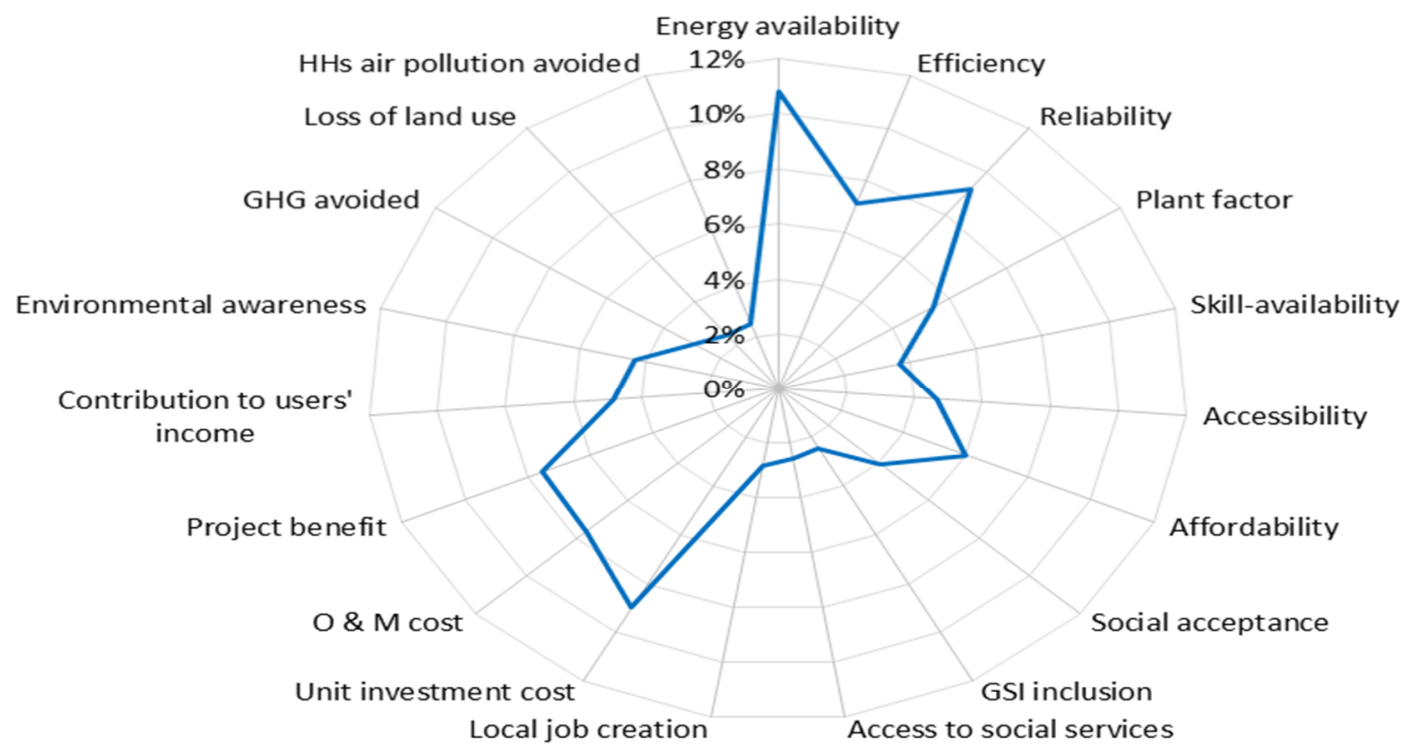

Figure 3: Consolidated global priorities of sub-criteria from experts' input

Figure 3 provides the spider diagram illustrating the weightage of sub-criteria (indicators), where the star at the core of the web represents the least priority weightage and star at the farthest outmost surface of the web represents the highest priority weightage. The results reveal that 'energy availability', 'reliability' and 'unit investment cost' are the most prioritized indicators. This points out the fact that renewable energy sources with high potential for 'energy availability', and 'reliability' and lower potential of 'unit investment cost' are the key indicators for sustainable energy generation projects. Likewise 'O\&M cost', 'project benefit', 'efficiency' and 'affordability' are also found to be major indicators from sustainability perspectives. It refers that concern stakeholders should take care of these indicators while addressing sustainability of off-grid technologies for rural electrification. 'Gender and social inclusion', 'household air pollution', 'loss of land use', 'access to social services', and 'local job creation' are found to be least prioritized indicators from the perspective of sustainability. Rest of the indicators - 'plant factor', 'contribution to users' income', 'accessibility', 'environmental awareness', 'social acceptance', 'skill-availability' and 'greenhouse gas avoided' are seen as moderately prioritized by the experts.

In order to see if there is any discrepancy in preference on the selected sub-criteria based on five stakeholders' group, preferences were computed varying with those groups and presented in the following Figure 4.

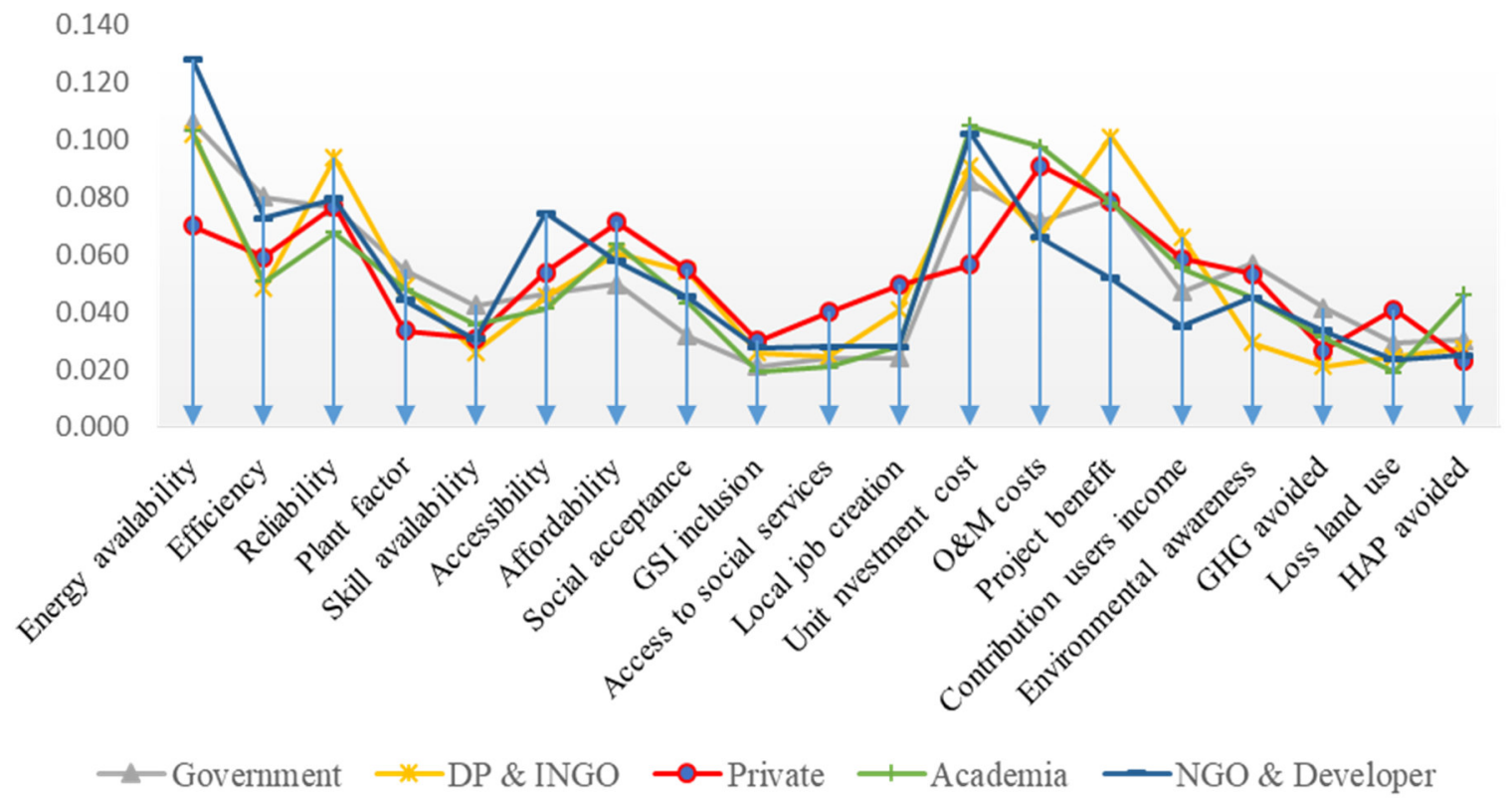

Figure 4: Distribution of weights for sub-criteria among five-expert' groups 
Figure 4 shows that there is both convergence as well as divergence of preferences among the five different stakeholders/experts groups. In general, we can observe convergence of preference on the most of the cases. In case of 'energy availability' and 'unit investment cost', besides private sector all four-groups have put the highest preference. Similarly, in case of 'efficiency', 'reliability', 'affordability', 'social acceptance', 'GSI inclusion' all the group result is converged. However, divergence cases are also seen in the figure. For instant, NGO \& Developer gave more preference on 'accessibility' and least 'preference on 'O\&M cost', 'project benefit' and 'contribution to users' income' in contrast to other group. Likewise, DP\&INGO think that 'project benefit' has more potential and 'GHG avoided' has less potential in contribution to sustainability of energy system. Similarly, private sector perceive that 'access to social service', 'local job creation' and 'loss of land use' has a bit higher role for sustainable operation of energy services.

However, ANOVA test performed among sub-criteria (indicators) and sector-wise responses signifies that there is not significance difference in mean value of each sub-criteria weightage among the stakeholders' group (which ranges from $\mathrm{F}_{4,86}=0.502, \mathrm{p}>0.05$ to $\mathrm{F}_{4,86}=2.255, \mathrm{p}>0.05$ ). Therefore, it can be concluded that the mean priority weightage of each sub-criteria and criteria among the five stakeholders' group is same as aggregate figure (consolidated global priority).

Moreover, AHP group consensus is found to be $70 \%$, which is moderate consensus according to the definition by Dr. Klaus (Goepel 2018). It means aggregate consensus from the group members ( 91 respondents) is estimated to be $70 \%$ which implies that the result of global priorities are moderately homogeneous in the research. Overall consistency ratio is found to be $0.45 \%$ and individual consistency ratio is $10 \%$ or less. Thus, the model of prioritizing the sustainability criteria and sub-criteria from the expert opinion is validated.

The limitation of the study is exclusion of institutional and political dimensions which are also key criteria for sustainability of rural electrification. Moreover, the study is entirely relying on experts' opinion. Therefore, future research is necessary to validate it based on project specific information.

\section{Discussion}

Based on the assessment result, some general remarks are drawn regarding the selected assessment framework, criteria and sub-criteria (renewable energy systems). Looking the stakeholders'/experts preference on the selected criteria (sustainability dimension), technical (0.362) is mostly prioritized followed by economic (0.290) and social (0.226). Environment (122) is least preferred criteria for sustainability of decentralized micro-hydropower in Nepalese contexts. The results have come together with the outcomes from previous studies carried for developing countries (Dhital et al. 2018; Lee \& Chang 2018); whereas it is diverted in case of developed countries (Demirtas 2013; Haddad et al. 2017; Çolak \& Kaya 2017; Stojanovic 2013). The behavior of the results implies that preference of sustainability criteria vary from country to country based on its resource availability and technological maturity. While comparing the priority of sustainability dimensions, environmental criteria seems to be most concern matters in relatively developed countries, whereas technical and economic criteria are preferred in the relatively developing countries.

Local stakeholders/experts, in general, (Figure 3) expressed high preference for 'Energy availability', 'unit investment cost', O\&M cost, 'project benefit 'reliability', and low preference on 'GHG emission avoided', 'loss of land use', 'HHs air pollution avoidance', 'GSI inclusion', which implies that preference is focused relatively on local benefit rather than regional and global benefits. However, in some cases preferences are diverged, if we compare the judgement based on individual stakeholders groups (Figure 4). But, statistical test suggests that there is no significance difference in mean value of judgement among the stakeholder group.

As discussed above, people from developed world take care more about the environment and social issues while developing a project, whereas people from developing world prefer technical and financial issues rather than environment and social issues. As Nepal is a developing country, people preferred the development of energy systems first with relatively low cost without considering the environment and gender/social inclusion. As a result, technical and economic criteria/sub-criteria are preferred more compared with environmental and social criteria/sub-criteria.

The result implies that the MCDM assessment framework can be useful for evaluation of current as well as future renewable energy systems including micro-hydropower projects at local level by incorporating local experts'/stakeholders' preferences in the process. Involvement of local stakeholders enhances legitimacy, transparency (Braune et al. 2009) and ownership in the framework and a result it helps to ensure consensus on the outcomes and also creates conducive environment for improvement on policies, plans and procedures.

\section{Conclusion}

As per stakeholders' judgements, technical criteria is observed to be the most crucial criteria for sustainability of decentralized rural electrification with highest priority weight followed by economic and social criteria. Environmental criteria is found to be the least preferred sustainability criteria. Comparing the consolidated (normalized) global priorities of sub-criteria, 'energy availability' is observed to the most preferred and GSI 
inclusion is ranked to be the least preferred indicator among the 19 sub-criteria. Similarly, 'reliability and 'unit investment cost' are also seen as crucial sub-criteria that need to be properly considered while addressing future pathways of decentralized rural electrification in Nepal. As Nepal is a developing country, people prefer the development of energy systems first at relatively low cost without considering the environment and gender inclusion. As a result, technical and economic criteria / sub-criteria are preferred more than environmental and social.

Therefore, it can be concluded that the proposed 'MCDM assessment framework' based on AHP-OS model enables a basis for prioritizing the criteria and sub-criteria for analyzing sustainability assessment of energy system; providing an effective decision making tool in rural electrification and development field.

The outcome of the research will help decision-makers and policy-makers in shaping energy policies, plans and programs, and foster future pathways for providing sustainable rural electrification in the country. Similarly, relevant stakeholders will be benefited to improve their priorities in proper aspects of products and services in the future.

\section{Acknowledgements}

The authors would like to thank respondents for their participation in the online survey. We gratefully acknowledge "AHP-OS author: Klaus D. Goepel" for his support in allowing the use of his software and for his valuable contribution, especially in solving problems.

\section{References}

Abreu Kang, T. H., da Costa Soares Júnior, A. M., \& de Almeida, A. T. (2018). Evaluating electric power generation technologies: A multicriteria analysis based on the FITradeoff method. Energy, 165, 10-20. https://doi.org/10.1016/j.energy.2018.09.165.

AEPC. (2008). Micro-Mini Hydro Power Output and Household Verification Guidelines. Alternative Energy Promotion Centre.

AEPC. (2014). Reference Micro Hydro Power Standard. Kathmandu: Alternative Energy Promotion Centre.

AEPC. (2016). Piloting sustainability monitoring for micro hydro plants. Lalitpur.

AEPC. (2018). Progress at a Glance: A Year in Review FY 2074/75. Lalitpur.

Afgan, N. H., \& Carvalho, M. G. (2008). Sustainability assessment of a hybrid energy system. Energy Policy, 36(8), 2903-2910.

Ahmad, S., \& Tahar, R. M. (2014). Selection of renewable energy sources for sustainable development of electricity generation system using analytic hierarchy process: A case of Malaysia. Renewable Energy, 63, 458-466. https://doi.org/10.1016/j.renene.2013.10.001.

Al Garni, H., Kassem, A., Awasthi, A., Komljenovic, D., \& Al-Haddad, K. (2016). A multicriteria decision making approach for evaluating renewable power generation sources in Saudi Arabia. Sustainable Energy Technologies and Assessments, 16, 137-150. https://doi.org/10.1016/j.seta.2016.05.006.

Algarín, C. R., Llanos, A. P., \& Castro, A. O. (2017). An analytic hierarchy process based approach for evaluating renewable energy sources. International Journal of Energy Economics and Policy, 7(4), 38-47.

Amer, M., \& Daim, T. U. (2011). Selection of renewable energy technologies for a developing county: A case of Pakistan. Energy for Sustainable Development, 15(4), 420-435. https://doi.org/10.1016/j.esd.2011.09.001.

Bhandari, R., Saptalena, L. G., \& Kusch, W. (2018). Sustainability assessment of a micro hydropower plant in Nepal. Energy, Sustainability and Society, 8(3). https://doi.org/10.1186/s13705-018-0147-2.

Bhattacharyya, S. C. (2012). Review of alternative methodologies for analysing off-grid electricity supply. Renewable and Sustainable Energy Reviews, 16(1), 677-694. https://doi.org/https://doi.org/10.1016/j.rser.2011.08.033.

Braune, I., Pinkwart, A., \& Reeg, M. (2009). Application of multi-criteria analysis for the evaluation of sustainable energy systems - A review of recent literature. Dubrovnic Conference on Sustainable Development of Energy, Water and Environment Systems.

Brent, A. C., \& Rogers, D. E. (2010). Renewable rural electrification: Sustainability assessment of mini-hybrid off-grid technological systems in the African context. Renewable Energy, 35(1), 257-265. https://doi.org/10.1016/j.renene.2009.03.028.

Brundtland, G. H., Khalid, M., Agnelli, S., Al-Athel, S., \& Chidzero, B. (1987). Our common future. In New York.

Ciroth, A., Finkbeier, M., Hildenbrand, J., Klöpffer, W., Mazijn, B., Prakash, S., .. Valdivia, S. (2011). Towards a live cycle sustainability assessment: making informed choices on products. UNEP/SETAC Life Cycle Initiative.

Çolak, M., \& Kaya, İ. (2017). Prioritization of renewable energy alternatives by using an integrated fuzzy MCDM model: A real case application for Turkey. Renewable and Sustainable Energy Reviews, 80(February), 840 853. https://doi.org/10.1016/j.rser.2017.05.194.

Demirtas, O. (2013). Evaluating the best renewable energy technology for sustainable energy planning. 
International Journal of Energy Economics and Policy, 3(SPECIAL ISSUE), 23-33.

Dhital, R. P., Bajracharya, T. R., \& Shrestha, R. (2018). Multi-Criteria Decision Making for Sustainability of Renewable Energy System of Nepal. Journal of Energy Technologies and Policy, 8(3), 69-81.

Dhital, R. P., Parajuli, B., Bajracharya, T. R., \& Sthrestha, R. (2016). Sustainability Assessment of Rural Solar PV Water Pumping System in Nepal. (October). Retrieved from http://conference.ioe.edu.np/conf2014Papers/IOE-CONF-2014-43.pdf.

Doukas, H. C., Andreas, B. M., \& Psarras, J. E. (2007). Multi-criteria decision aid for the formulation of sustainable technological energy priorities using linguistic variables. European Journal of Operational Research, 182(2), 844-855. https://doi.org/10.1016/j.ejor.2006.08.037.

ESMAP. (2017). State of Electricity Access Rep ort (SEAR). Retrieved from http://esmap.org/SEAR/ (April 10, 2019).

Evans, A., Strezov, V., \& Evans, T. J. (2009). Assessment of sustainability indicators for renewable energy technologies. Renewable and Sustainable Energy Reviews, 13(5), 1082-1088. https://doi.org/10.1016/j.rser.2008.03.008.

Feron, S. (2016). Sustainability of off-grid photovoltaic systems for rural electrification in developing countries: A review. Sustainability (Switzerland), 8(12), 1-26. https://doi.org/10.3390/su8121326.

Feron, S., Heinrichs, H., \& Cordero, R. R. (2016). Are the rural electrification efforts in the Ecuadorian Amazon sustainable? Sustainability (Switzerland), 8(5), 1-22. https://doi.org/10.3390/su8050443.

Goepel, K. D. (2018). Implementation of an Online Software Tool for the Analytic Hierarchy Process (AHP-OS). International Journal of the Analytic Hierarchy Process, 10(3), 469-487.

Haddad, B., Liazid, A., \& Ferreira, P. (2017). A multi-criteria approach to rank renewables for the Algerian electricity system. Renewable Energy, 107, 462-472. https://doi.org/10.1016/j.renene.2017.01.035.

Hong, G. W., \& Abe, N. (2012). Sustainability assessment of renewable energy projects for off-grid rural electrification: The Pangan-an Island case in the Philippines. Renewable and Sustainable Energy Reviews, 16(1), 54-64. https://doi.org/10.1016/j.rser.2011.07.136.

IAEA. (2005). Energy Indicators for Sustainable Development : Guidelines and Methodologies. Vienna.

Ilskog, E. (2008). Indicators for assessment of rural electrification-An approach for the comparison of apples and pears. Energy Policy, 36(7), 2665-2673. https://doi.org/10.1016/j.enpol.2008.03.023.

Ilskog, E., \& Kjellström, B. (2008). And then they lived sustainably ever after?-Assessment of rural electrification cases by means of indicators. Energy Policy, 36(7), 2674-2684. https://doi.org/10.1016/j.enpol.2008.03.022.

Kaya, T., \& Kahraman, C. (2010). Multicriteria renewable energy planning using an integrated fuzzy VIKOR \& AHP methodology: The case of Istanbul. Energy, 35(6), 2517-2527. https://doi.org/10.1016/j.energy.2010.02.051.

Kemmler, A., \& Spreng, D. (2007). Energy indicators for tracking sustainability in developing countries. Energy Policy, 35(4), 2466-2480. https://doi.org/10.1016/j.enpol.2006.09.006.

Kumar, A., Sah, B., Singh, A. R., Deng, Y., He, X., Kumar, P., \& Bansal, R. C. (2017). A review of multi criteria decision making (MCDM) towards sustainable renewable energy development. Renewable and Sustainable Energy Reviews, 69(November 2016), 596-609. https://doi.org/10.1016/j.rser.2016.11.191.

Lee, H. C., \& Chang, C. Ter. (2018). Comparative analysis of MCDM methods for ranking renewable energy sources in Taiwan. Renewable and Sustainable Energy Reviews, 92(May), 883-896. https://doi.org/10.1016/j.rser.2018.05.007.

Liu, G., Baniyounes, A. M., Rasul, M. G., Amanullah, M. T. O., \& Khan, M. M. K. (2013). General sustainability indicator of renewable energy system based on grey relational analysis. International Journal of Energy Research, 37(14), 1928-1936.

Mainali, B., Pachauri, S., Rao, N. D., \& Silveira, S. (2014). Assessing rural energy sustainability in developing countries. Energy for Sustainable Development, 19, 15-28.

Mainali, B., \& Silveira, S. (2015). Using a sustainability index to assess energy technologies for rural electrification. Renewable and Sustainable Energy Reviews, 41, 1351-1365. https://doi.org/10.1016/j.rser.2014.09.018.

Mamlook, R., Akash, B. A., \& Mohsen, M. S. (2001). A neuro-fuzzy program approach for evaluating electric power generation systems. Energy, 26(6), 619-632. https://doi.org/10.1016/S0360-5442(01)00015-9.

NPC. (2017). National Report on the Implementation of the 2030 Agenda for Sustainable Development. Kathmandu: GoN, National Planning Commissioning.

Onat, N., \& Bayar, H. (2010). The sustainability indicators of power production systems. Renewable and Sustainable Energy Reviews, 14(9), 3108-3115. https://doi.org/10.1016/j.rser.2010.07.022.

PwC. (2016). Electricity beyond the grid: Accelerating access to sustainable power for all. PwC Global Power \& Utilities, 1-24.

Qureshi, M. E., \& Harrison, S. R. (2003). Application of the analytic hierarchy process to riparian revegetation policy options. Small-Scale Forest Economics, Management and Policy, 2(3), 441. 
Rojas-Zerpa, J. C., \& Yusta, J. M. (2015). Application of multicriteria decision methods for electric supply planning in rural and remote areas. Renewable and Sustainable Energy Reviews, 52, 557-571. https://doi.org/10.1016/j.rser.2015.07.139.

Saaty, R. W. (1987). The analytic hierarchy process - what it is and how it is used. Mathematical Modelling, $9(3-$ 5), $161-176$.

Saaty, T. L. (1986). Axiomatic foundation of the analytic hierarchy process. Management Science, 32(7), 841855.

Saaty, T. L. (1994). How to make a decision: the analytic hierarchy process. Interfaces, 24(6), 19-43.

Saaty, T. L., \& Vargas, L. G. (2012). Models, methods, concepts \& applications of the analytic hierarchy process (Vol. 175). Springer Science \& Business Media.

Saaty T.L. (2008). Decision making with the analytic hierarchy process. International Journal of Services Sciences, 1(1), 83. https://doi.org/10.1504/IJSSCI.2008.017590.

Santoyo-Castelazo, E., \& Azapagic, A. (2014). Sustainability assessment of energy systems: Integrating environmental, economic and social aspects. Journal of Cleaner Production, 80(2014), 119-138. https://doi.org/10.1016/j.jclepro.2014.05.061.

Şengül, Ü., Eren, M., Shiraz, S. E., Gezder, V., \& Şengül, A. B. (2015). Fuzzy TOPSIS method for ranking renewable energy supply systems in Turkey. Renewable Energy, 75, 617-625.

Singh, R. P., \& Nachtnebel, H. P. (2016). Analytical hierarchy process (AHP) application for reinforcement of hydropower strategy in Nepal. Renewable and Sustainable Energy Reviews, 55, 43-58. https://doi.org/10.1016/j.rser.2015.10.138.

Soma, K. (2003). How to involve stakeholders in fisheries management - a country case study in Trinidad and Tobago. Marine Policy, 27(1), 47-58.

Stojanovic, M. (2013). Multi-Criteria decision-making for selection of Renewable Energy Systems. Safety Engineering, 115. https://doi.org/10.7562/SE2013.3.02.02.

Thapa, RB; Upreti, B.; Devkota, D.; Pokharel, G. (2019). Analytical Hierarchy Process (AHP) application for identifying the best renewable energy system for rural electrification in Nepal. In 2nd Latin American Workshop on Energy Transition- Addressing Sustainable Development.

Thapa, R. B. (2017). Off-Grid Energy an Option for Rural Energy Solution. Imperial Journal of Interdisiciplinary Research, 3(9), 1064-1070.

Thapa, R. B. (2019). Prioritizing Criteria and its relevant Indicators for the sustainability of micro-hydro projects in Nepal. Retrieved April 15, 2019, from Web Page website: http://sustainabilityres.home.blog/informedconsent-form- $2 /$.

UNDP. (2007). Indicators for sustainable development. United Nations Division for Sustainable Development 2007.

UNDP. (2014). Discussion Paper, Integrated sustainable rural development: renewable energy electrification and rural productivity zones.

Wang, J. J., Jing, Y. Y., Zhang, C. F., \& Zhao, J. H. (2009). Review on multi-criteria decision analysis aid in sustainable energy decision-making. Renewable and Sustainable Energy Reviews, 13(9), 2263-2278. https://doi.org/10.1016/j.rser.2009.06.021.

WB. (2015). Nepal: Scaling Up Electricity Access through Mini and Micro Hydropower Applications: A strategic stock-taking and developing a future roadmap. Retrieved from http://documents.worldbank.org/curated/en/650931468288599171/pdf/96844-REVISED-v1-Micro-HydroReport-0625-2015-Final.pdf.

Zen, A. C., Lima, A., Bianchi, A. L., \& Babot, L. (2016). Sustainability, Energy and Development: A Proposal of Indicators. International Journal for Infonomics, 5(1/2), 537-541. https://doi.org/10.20533/iji.1742.4712.2012.0060. 